\title{
A LINKAGE STUDY WITH DNA MARKERS (D4S95, D4S115, AND D4S111) IN JAPANESE HUNTINGTON DISEASE FAMILIES
}

\author{
Masahiko Watanabe, ${ }^{1}$ Ikuko Kondo, ${ }^{2}$ Sumiko NisSato, ${ }^{3}$ \\ Akemi Wakisaka, ${ }^{4}$ Tatsushi Toda, ${ }^{1}$ Joh-e Ikeda, ${ }^{5}$ \\ John J. Wasmuth, ${ }^{6}$ James F. Gusella, ${ }^{7}$ and Ichiro Kanazawa ${ }^{1, *}$ \\ ${ }^{1}$ Department of Neurology, Institute of Brain Research, University of Tokyo, \\ Bunkyo-ku, Tokyo 113, Japan \\ ${ }^{2}$ Department of Hygiene, Ehime University, School of Medicine, \\ Onsen-gun, Ehime 791-02, Japan \\ ${ }^{3}$ Department of Neurology, Institute of Clinical Medicine, University of Tsukuba, \\ Tsukuba 305, Japan \\ ${ }^{4}$ Department of Pathology, School of Medicine, Hokkaido University, Sapporo 060, Japan \\ ${ }^{5}$ Ikeda Genosphere Project, ERATO, JRDC, Tokai University School of Medicine, \\ Isehara, Kanagawa 259-11, Japan \\ ${ }^{6}$ Department of Biological Chemistry, University of California, Irvine \\ ${ }^{7}$ Neurogenetics Laboratory, Massachusetts General Hospital and Department of Genetics, \\ Harvard Medical School, Boston, Massachusetts
}

\begin{abstract}
Summary Attempts to isolate the Huntington disease (HD) gene based on its position have been frustrated by apparently contradictory recombination events in HD pedigrees that have predicted two non-overlapping candidate regions: $100 \mathrm{~kb}$ at the telomere of the short arm of chromosome 4, and a $2.2 \mathrm{Mb}$ region located internally at $4 \mathrm{p} 16.3$. The proximal location is also supported by the detection of a linkage disequilibrium between HD and some restriction fragment length polymorphisms (RFLPs) at the D4S95, D4S98, and D4S127 loci. In the present study, a proximal marker D4S95 showed tight linkage to the disease locus in Japanese pedigrees $\left(Z_{\max }=3.31, \theta_{\text {max }}=0.00\right)$, while distal markers D4S115 and D4S111 did not. Particularly, a two point linkage analysis between D4S111 and HD yielded a lod score -2.01 for $\theta=0.015$. This result leads to the exclusion, as a possible region of localization of the HD gene, of more than $3 \mathrm{cM}$ of the genome around D4S111 locus. At the same time our results favor aforementioned proximal location as a candidate location for the HD gene.
\end{abstract}

Key Words Huntington disease, linkage analysis, D4S95, D4S115, D4S111

Received March 30, 1993; Revised Accepted April 13, 1993.

* Reprint request to: I. Kanazawa, M.D. 


\section{INTRODUCTION}

Huntington disease (HD) is a progressive neurodegenerative disorder that is inherited as an autosomal dominant and highly penetrant trait. The three cardinal symptoms of this disorder are (1) choreic movements, (2) mental defect, and (3) change in personality. The disease usually begins between the age of 30 and 45 years and progress unremittingly for 15-20 years. The neuropathologic hallmark of the disorder is a marked atrophy of the basal ganglia, particularly of the caudate nucleus. However, little is known about the biochemical basis of the neuronal cell death in the disorder.

Genetic linkage analysis with DNA marker D4S10 (G8) mapped HD to the short arm of chromosome 4 (Gusella et al., 1983, 1985). Multipoint linkage analysis established that the HD gene is $4 \mathrm{cM}$ distal to D4S10 and is located at $4 \mathrm{p} 16.3$, the terminal cytogenetic subband of chromosome 4 (Gilliam et al., 1987; MacDonald et al., 1987). All subsequent families tested showed linkage to this region (Coneally et al., 1989), suggesting that a single locus is mutated in all individuals affected with the disease. D4S111 and D4S115 were derived from a Not I linking library generated from a somatic cell hybrid, HHW693 (Pohl et al., 1988). Both loci show multiallele RFLPs of variable number of tandem repeat (VNTR) type (Nakamura et al., 1987). Each of these loci was tightly linked to the HD gene in a large Ven-

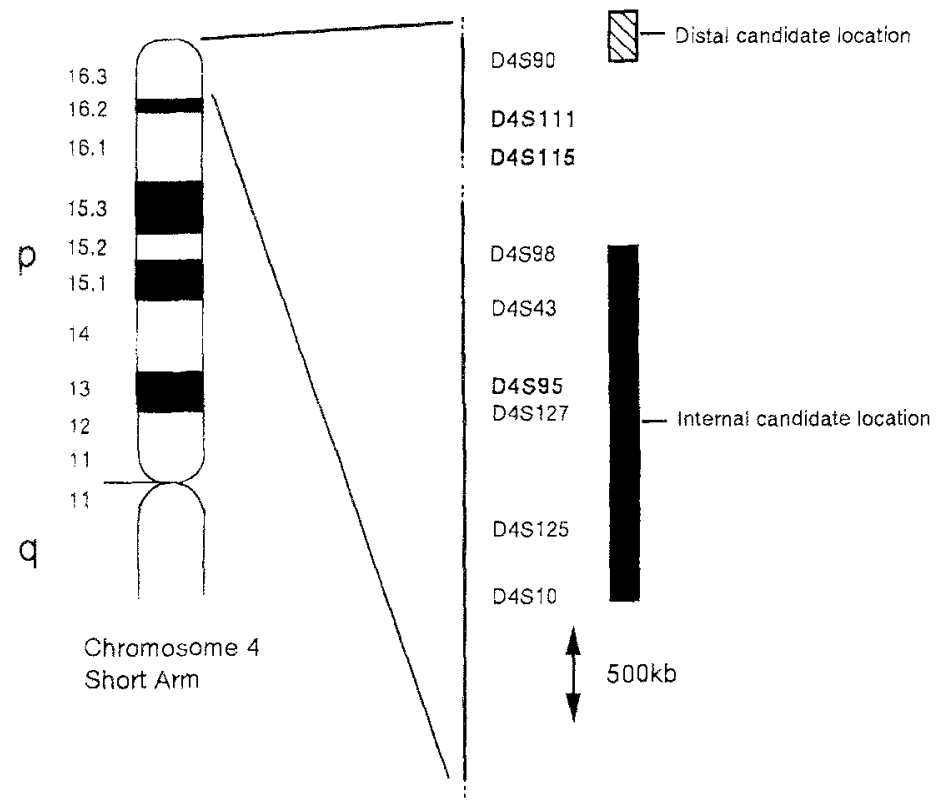

Fig. 1. Placement of DNA marker loci on the physical map of $4 \mathrm{p} 16.3$ (modified from MacDonald ME et al., 1989A). D4S95 is located in the proxymal candidate Iocation, while both D4S115 and D4S111 are distal to it. 
ezuelan kindred and several smaller pedigrees from the U.S. and Europe, and was tightly linked to the other locus, with no recombinants in 179 informative meioses in reference pedigrees (MacDonald et al., 1989a). Complementary genetic (MacDonald et al., 1989b; Youngman et al., 1989; Allito et al., 1991) and physical (Bucan et al., 1990) (Fig. 1) maps of 4p16.3 were generated. In these maps, D4S115 and D4S111 are $250 \mathrm{~kb}$ apart and are located distal to D4S98/S114/S113 (Pohl et al., 1988), while D4S95 is proximal to it (Fig. 1). Recombination events with HD have not decisively positioned the HD gene but suggest two non-overlapping locations (MacDonald et al., 1989b). Three events indicated a location close to the telomere, distal to all known RFLP markers (Fig. 1, the distal candidate location) (MacDonald et al., 1989b; Robbins et al., 1989). In contrast, a more proximal location was defined at its distal boundary by a recombination between D4S43 and D4S98 (Fig. 1, the internal candidate location) (Snell et al., 1992). The proximal location was also supported by the detection of linkage disequilibrium between HD and some RFLPs at the D4S95, D4S98, and D4S127 loci (Snell et al., 1989; Theilmann et al., 1989; Adam et al., 1991; MacDonald et al., 1991, 1992). Recently, a new gene, IT15, isolated from the proxymal candidate location contains a polymorphic trinucleotide repeat that is expanded on HD chromosomes (The Huntington's Disease Collaborative Research Group, 1993).

In this study, we analyzed 18 Japanese kindreds using these two distal markers (D4S115 and D4S111) and D4S95.

\section{MATERIALS AND METHODS}

Subjects. Families of documented history of HD were ascertained (Kanazawa et al., 1990). A total of 18 Japanese kindreds were examined for linkage between the HD gene and the DNA markers D4S95, D4S115, and D4S111.

DNA probes. The following chromosome loci were used in the linkage study: D4S95, probe BS674 which detects $A c c \mathrm{I}, M b o \mathrm{I}$, and TaqI polymorphisms (Wasmuth et al., 1988; Smith et al., 1988); D4S111, probe p157.9 which detects Pst I polymorphism (MacDonald et al., 1989a; Whaley et al., 1988); D4S115, probe p252.3 which detects a PstI polymorphism (Bucan et al., 1990; Poustka et al., 1987).

$D N A$ and hybridization. Epstein-Barr virus-transformed lymphoblastoid cell lines and cultured peripheral blood lymphocytes were used as a source DNA from members of the 18 Japanese HD pedigrees. DNA was extracted from lymphocytes and lymphoblasts using the method of Kunkel et al. (1977). DNA (5 $\mu \mathrm{g})$ from these cells was digested with appropriate restriction endonucleases ( $\mathrm{AcCl}$, $\mathrm{MboI}$, Pst I, or TaqI), fractionated on $0.8-1.0 \%$ agarose gels and transferred to GeneScreen (Du Pont, NEN Research) in an alkaline solution (0.5 N NaOH, $1.5 \mathrm{~N} \mathrm{NaCl})$. Southern blots were prehybridized in a hybridization solution containing $200 \mu \mathrm{g} / \mathrm{ml}$ of denatured salmon sperm DNA, and hybridized at $65^{\circ} \mathrm{C}$ overnight in the same buffer with probes radioactively labeled by random priming (Feinberg and Vogel- 
stein, 1983) ("random primer DNA labeling kit," Takara Shuzo), as described previously (Nguyen et al, 1987). The filters were washed with $0.5 \times \mathrm{SSC}, 1 \%$ SDS or $0.2 \times \mathrm{SSC}, 1 \% \mathrm{SDS}$ at $55-60^{\circ} \mathrm{C}$ prior to autoradiography at $-70^{\circ} \mathrm{C}$ for 1-5 days using X-ray film (X-OMAT, Kodak) with intensifying screen.

Linkage analysis. Two-point linkage analysis was performed using the LIPED program, version 3 (Ott, 1976; Hodge et al., 1979), which incorporates age correction. Autosomal dominant inheritance of a rare gene (frequency $0.0001 \%$ ) (Kanazawa, 1982) was assumed, and final penetrance was estimated at 1.00 in our families. Parameters for the age correction were based on age-at-onset data on affected individuals in the Japanese population (Kanazawa, 1982). Allele frequencies for the various markers used were estimated by counting alleles in the married-in-individuals in ouripedigrees.

\section{RESULTS}

RFLPS

As summarized in Table 1 , the $1 \mathrm{~kb}$ probe, BS674, defining the genetic locus D4S95 (Wasmuth et al., 1988), detected three separate polymorphic sites using three restriction endonucleases ( $A c c \mathrm{I}, \mathrm{MboI}$, and TaqI). PIC values for $A c c \mathrm{I}$, $M b o I$, and TaqI polymorphisms are $0.22,0.24$, and 0.31 , respectively. VNTR-like RFLPs were found when probes from cosmids overlapping two NotI linking clones

Table 1. RFLPs at D4S95, D4S115, and D4S111.

\begin{tabular}{|c|c|c|c|c|c|}
\hline Locus & $\begin{array}{l}\text { Probe } \\
\text { name }\end{array}$ & $\begin{array}{l}\text { Restriction } \\
\text { enzyme }\end{array}$ & $\begin{array}{l}\text { Allelic } \\
\text { fragment } \\
\text { (kb) }\end{array}$ & $\begin{array}{l}\text { Allele } \\
\text { frequency } \\
\text { tested }\end{array}$ & $\begin{array}{l}\text { Polymorphic } \\
\text { information } \\
\text { content }\end{array}$ \\
\hline \multirow[t]{6}{*}{ D4S95 } & BS674 & $A c c \mathrm{I}$ & 6.8 & 0.86 & 0.22 \\
\hline & & & 1.5 & 0.14 & \\
\hline & & Mbol & 1.3 & 0.83 & 0.24 \\
\hline & & & $0.7+0.6$ & 0.17 & \\
\hline & & Taql & 2.3 & 0.74 & 0.31 \\
\hline & & & 1.7 & 0.26 & \\
\hline \multirow[t]{6}{*}{ D4S115 } & $\mathrm{p} 252.3$ & $p_{s t} \mathrm{I}$ & 3. 30 & 0.14 & 0.77 \\
\hline & & & 2.55 & 0.11 & \\
\hline & & & 2.44 & 0.14 & \\
\hline & & & 2. 41 & 0.33 & \\
\hline & & & 2. 38 & 0.25 & \\
\hline & & & 2. 32 & 0.03 & \\
\hline \multirow[t]{3}{*}{ D4S111 } & p157.9 & Pst 1 & 2.20 & 0.39 & 0.65 \\
\hline & & & 2. 11 & 0.36 & \\
\hline & & & 2. 01 & 0.25 & \\
\hline
\end{tabular}




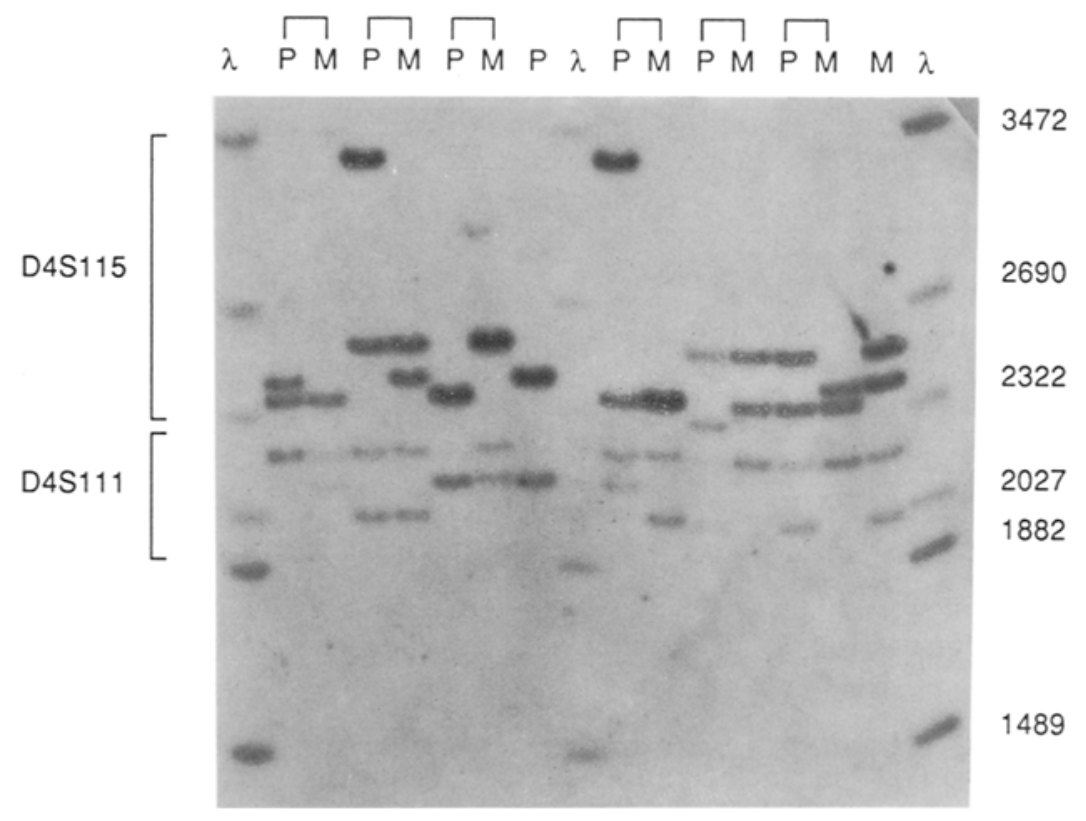

Fig. 2. Simultaneous hybridization with two probes (D4S115 and D4S111) detecting multi-allele RFLPs near the Huntington disease gene and a probe detecting lambda DNA. The potential for simultaneous detection of the RFLPs was tested by hybridization to Pst I-digested DNAs from reference families. $\mathrm{P}$ and $M$ indicate the father and mother of each reference family respectively. Lane 1 contains EcoT141-digested lambda DNA.

were used. These probes, p157.9 and p252.3, define the loci D4S111 and D4S115 (Pohl et al., 1988; Bucan et al., 1990; Poustka et al., 1987), respectively, which are located $250 \mathrm{~kb}$ apart, and are both distal to D4S95. As shown in Fig. 2, these two multi-allele RFLPs were able to be visualized using Pst I simultaneously. As these polymorphism possesses high PIC values (0.77 for D4S115 and 0.65 for D4S111) larger than 0.5, they are considered to be highly informative (Botstein et al., 1980).

\section{Pairwise analysis}

Segregation of the DNA markers was analyzed by the computer program LIPED (Ott, 1976; Hodge et al., 1979) to calculate the likelihood of linkage for various values of $\theta$, the recombination fraction, relative to the likelihood of nonlinkage $(\theta=0.5)$. Table 2 presents the results of these calculations as a lod score $(z, \log 10$ of the likelihood ratio) for each value of $\theta$. Significant linkage was detected for the marker D4S95. Five families gave informative results for linkage with probe $\mathrm{p} 674$ (D4S95). It is tightly linked to HD, giving a maximum likelihood estimate of $\theta=0.00\left(Z_{\max }=3.31\right)$. We previously reported the tight linkage between D4S43 and $\operatorname{HD}\left(Z_{\mathrm{max}}=3.348\right.$ for $\left.\theta=0.00\right)$ (Kanazawa et al., 1990). These two 
Table 2. Pairwise lod scores for linkage of 4 p16.3 makers to HD.

\begin{tabular}{|c|c|c|c|c|c|c|c|c|c|}
\hline \multirow{2}{*}{ Locus 1} & \multirow{2}{*}{ Locus 2} & \multicolumn{6}{|c|}{ Recombinaion fraction $(\theta)$} & \multicolumn{2}{|c|}{$\underset{\text { score }}{\text { Maximum loc }}$} \\
\hline & & 0.00 & 0.01 & 0.05 & 0.10 & 0.20 & 0.25 & $Z_{\max }$ & $\theta_{\max }$ \\
\hline HD & D4S95 & 3.31 & 3.27 & 3.09 & 2.79 & 2.01 & n.d. & 3.31 & 0.00 \\
\hline HD & D4S115 & $-\infty$ & 0.07 & 1.55 & 1.91 & 1.67 & 1.37 & 1.92 & 0.12 \\
\hline HD & D4S111 & $-\infty$ & -2.52 & -0.67 & 0.01 & 0.34 & 0.31 & 0.34 & 0.20 \\
\hline D4S95 & D4S115 & -198 & 0.14 & 1.27 & 1.51 & 1.24 & 0.96 & 1.51 & 0.11 \\
\hline D4S95 & D4S111 & n.d. & 1.24 & 2.34 & 2. 44 & n.d. & n.d. & 2.46 & 0.08 \\
\hline D4S 115 & D4S111 & n.d. & n.d. & n.d. & 4.06 & 3.42 & 2.77 & 4.07 & 0.11 \\
\hline
\end{tabular}

not determined.

loci (D4S95 and D4S43) were mapped to the same segment in the physical map of this region (Bucan et al., 1990). There was significant linkage between these two loci in our pedigrees, too $\left(Z_{\max }=4.12\right.$ at $\left.\theta_{\max }=0.03\right)$.

There was no significant linkage between D4S115 and HD. The maximum lod score was 1.92 at $\theta=0.12$. A two point linkage analysis between the marker D4S111 and the HD gene yielded a lod score -2.055 for $=0.015$.

\section{DISCUSSION}

Recombination events with HD have not decisively positioned the HD gene but suggest two non-overlapping locations (MacDonald et al., 1989b). Three events indicate a location close to telomere, distal to all known RFLP markers (MacDonald et al., 1989b; Robbins et al., 1989) (The distal candidate location). In contrast, the more proximal location is defined at its distal boundary by a discrete recombination event occurring between two markers i.e., D4S113 and D4S168 (MacDonald et al., 1989b; Whaley et al., 1991) (The internal candidate location). The proximal genetic limit to the location of HD was defined (Bates et al., 1991). They found the critical recombination event occurring between D4S10 and D4S125. Extending from a crossover event occurring between D4S10 and D4S125 to one between D4S113 and D4S168, the internal candidate location spans as much as $2.5 \mathrm{Mb}$. The distal boundary of this region has recently been redefined by a crossover event occurring between D4S43 and D4S98 (Snell et al., 1992), thereby reducing the maximal size of the region from 2.5 to $2.2 \mathrm{Mb}$. The internal location is also supported by the detection of a linkage disequilibrium i.e., the non-random association of marker alleles with disease mutation, between HD gene and some RFLPs at the D4S95 and D4S98 loci (Snell et al., 1989; Theilmann et al., 1989; Adam et al., 1991; MacDonald et al., 1991, 1992). In addition, a new gene, IT15, isolated from the proxymal condidate location contains a polymorphic trinucleotide repeat that is expanded on HD chromosomes (The Huntington Disease Collaborative Research Group, 1993). 
In the present study, a proximal marker D4S95 showed tight linkage to the disease locus in Japanese pedigrees, while distal markers D4S115 and D4S111 did not. As shown in Fig. 1, D4S95 is located in the proxymal candidate location, while both D4S115 and D4S111 are distal to it. There was a gradual loss of positive lod scores as we go through proximal to distal. Particularly, a two point linkage analysis between D4S111 and HD yielded a lod score -2.01 for $\theta=0.015$. As a lod score of $\leq-2$ is used in determining whether exclusionary evidence is obtained (Morton, 1955), our result lead to the exclusion, as a possible region of localization of the HD gene, of more than $3 \mathrm{cM}$ of the genome around D4S111 locus. At the same time, our results favor aforementioned proximal location as a candidate location for the HD gene.

Acknowledgments This study was supported by grants for Scientific Research on Priority Areas (04258102) and for Scientific Research (04404041), Ministry of Education, Science and Culture of Japan.

\section{REFERENCES}

Adam S, Theilmann J, Buetow K, Hedrick A, Collins C, Weber B, Huggins M, Hayden M (1991): Linkage disequilibrium and modification of risk for Huntington disease. Am J Hum Genet 48: 595-603

Allitto BA, MacDonald ME, Bucan M, Richards J, Romano D, Whaley WL, Falcone B, Ianazzi J, Wexler NS, Wasmuth JJ, Collins FS, Lehrech H, Haines JL, Gusella JF (1991): Increased recombination adjacent to the Huntington disease-linked D4S10 marker. Genomics 9: 104 12

Bates GP, MacDonald ME, Baxendale S, Youngman S, Lin C, Whaley WL, Wasmuth JJ, Gusella JF, Lehrach H (1991): Defined physical limits of the Huntington disease gene candidate region. Am J Hum Genet 49: 7-16

Botstein D, White RL, Skolnick M, Davis RW (1980): Construction of a genetic linkage map using restriction fragment length polymorphisms. Am J Hum Genet 32: 314-331

Bucan M, Zimmer M, Whaley WL, Poustka A, Youngman S, Allito BA, Ormondroyd E, Smith B, Pohl TM, MacDonald M, Bates GP, Richards J, Volinia S, Gilliam TC, Sedracek Z, Collins FS, Wasmuth JJ, Shaw DJ, Gusella JF, Frischauf A-M, Lehrach H (1990): Physical maps of 4p16.3, the area expected to contain the Huntington's disease mutation. Genomics 6: 1-15

Conneally PM, Haines JL, Tanzi RE, Wexler NS, Penchaszadeh GK, Harper PS, Folstein SE, Cassiman JJ, Myers RH, Young AB, Hayden MR, Falek A, Tolosa ES, Crespi S, Maio LD, Holmgren G, Anvret M, Kanazawa I, Gusella JF (1989): Huntington disease: No evidence for locus heterogeneity. Genomics 5: 304-308

Feinberg AP, Vogelstein B (1983): A technique for radiolabelling DNA restriction endonuclease fragments to high specific activity. Anal Biochem 132:6-13

Gilliam TC, Tanzi RE, Haines JL, Bonner TI, Faryniarz AG, Hobbs WJ, MacDonald ME, Cheng SV, Folstein SE, Conneally PM, Wexler NS, Gusella JF (1987): Localization of the Huntington's disease gene to a small segment of chromosome 4 flanked by D4S10 and the telomere. Cell 50: $565-571$

Gusella JF, Wexler NS, Conneally PM, Naylor SL, Anderson MAS, Tanzi RE, Watkins PC, Ottina K, Wallace MR, Sakuguti AY, Young AB, Shoulson I, Bonilla E, Martin JB (1983): A polymorphic DNA marker genetically linked to Hungtington's disease. Nature 306: 234-238 
Gusella JF, Tanzi RE, Bader PI, Phelan MC, Stevenson R, Hayden MR, Hofman KJ, Faryniarz AG, Gibbons K (1985): Deletion of the Huntington's discase linked G8(D4S10) locus in WolfHirschhorn syndrome. Nature 318: 75-78

Hodge SE, Morton LA, Tideman S, Kidd KK, Spence MA (1979): Age-of-onset correction available for linkage analysis (LIPED). Am J Hum Genet 31: 761-762

Kanazawa I (1982): On the prevalence r7te of Huntington's disease in Ibaraki prefecture. Annual Report of the Research Committee of CNS Degenerative Disease 1983: 151-156

Kanazawa I, Kondo I, Ikeda J, Ikeda T, Shizu Y, Yoshida M, Narabayashi H, Kuroda S, Tsunoda H, Mizuta E, Okuno Y, Sugawara K, Murata M, Takahashi M, Gusella JF (1990): Studies on DNA markers (D4S10 and D4S43/S127) genetically linked to Huntington's disease in Japanese families. Hum Genet 85: 257-260

Kunkel LH, Smith KD, Boyer SH, Borgaonkar HW, Rary JM (1977): Analysis of human Y-chromosome-specific reiterated DNA in chromosome variants. Proc Natl Acad Sci USA 74: 12451249

MacDonald ME, Anderson MA, Gilliam TC, Tranebjaerg L, Carpenter NJ, Magnenis E, Hayden MR (1987): A somatic cell hybrid panel for localizing DNA segments near the Huntington's disease gene. Genomics 1: 29-34

MacDonald ME, Cheng SV, Zimmer M, Haines JL, Poustka A, Allito B, Smith B, Whaley WL, Romano DM, Jagadeesh J, Myers RH, Lehrach H, Wasmuth J, Frieschauf AM, Gusella JF (1989a): Clustering of multi-allele DNA markers near the Huntington's disease gene. J Clin Invest 84: 1013-1016

MacDonald ME, Haines JL, Zimmer M, Cheng SV, Youngman S, Whaley WL, Wexler N, Bucan M, Allito BA, Smith B, Leavitt J, Poustka A, Harper P, Lehrach H, Wasmuth JJ, Frischauf AM, Gusella JF (1989b): Recombination events suggest potential sites for the Huntington's disease gene. Neuron 3: 183-190

MacDonald ME, Lin C, Srinidhi L, Bates G, Altherr M, Whaley WL, Lehrach H, Wasmuth J, Gusella JF (1991): Complex pattern of linkage disequilibrium in the Huntington disease region. Am J Med Genet 49: 723-734

MacDonald ME, Novelletto A, Lin C, Tagle D, Barnes G, Bates G, Taylor S, Allitto B, Altherr M, Myers R, Lehrach H, Collins FS, Wasmuth JJ, Frontali M, Gusella JF (1992): The Huntington's disease candidate region exhibits many different haplotypes. Nature Genet 1: 99103

Morton NE (1955): Sequencial tests for the detection of linkage. Am J Hum Genet 7: 277-318

Nakamura Y, Leppert M, O'Connell P, Wolff R, Holm T, Culver M, Martin C, Fujimoto E, Hoff M, Kumlin E, White R (1987): Variable number of tandem repeat (VNTR) markers for human gene mapping. Science 235: 1616-1622

Nguyen C, Pontarotti P, Birnbaum D, Chimini G, Ray JA, Mattei JF, Jordan BR (1987): Large scale physical mapping in teh $\mathrm{q} 27$ region of the human $\mathrm{X}$ chromosome: The coagulation factor IX gene and the mcf. 2 transforming sequence are separated by at most 270 kilobase pairs and are surrounded by several "HTF islands." EMBO I 6: 3285-3289

Ott $J$ (1976): A computer program for linkage analysis of general human pedigrees. Am $J$ Hum Genet 28: $528-529$

Pohl TM, Zimmer M, MacDonald ME, Smith B, Bucan M, Poustka A, Volinia S, Searle S, Zehetner G. Wasmuth JJ, Gusella JF, Lehrach H, Frischauf A-M (1988): Construction of a Not I linking library and isolation of new markers close to the Huntington's disease gene. Nucleic Acids Res 16: $9185-9198$

Poustka A, Poh] TM, Barlow DP, Frischauf A-M, Lehrach H (1987): Construction and use of human chromosome jumping library from Not I-digested DNA. Nature 325: 353-355

Robbins C, Theilmann J, Youngman S, Haines J, Altherr MJ, Harper PS, Payne C, Junker A, Wasmuth J, Hayden MR (1989): Evidence from family studies that the gene causing Huntington disease is telomeric to D4S95 and D4S90. Am J Hum Genet 44: 422-425

Jpn J Human Genet 
Smith B, Skarecky D, Bengtsson U, Magenis RE, Carpenter N, Wasmuth JJ (1988): Isolation of DNA markers in the direction of the Huntington disease gene from the G8 locus. Am $\mathbf{J}$ Hum Genet 42: 335-344

Snell RG, Lazarou LP, Youngman S, Quarrell O, Wasmuth JJ, Shaw DJ, Harper PS (1989): Linkage disequilibrium in Huntington's disease: An improved localisation for the gene. $J$ Med Genet 26: 673-675

Snell RG, Thompson LM, Tagle DA, Holloway TL, Barnes G, Harley HG, Sandkuijil LA, MacDonald ME, Collins FS, Gusella JF (1992): A recombination event that redifines the Huntington disease region. Am J Hum Genet 51 : 357-362

The Huntington's Disease Collaborative Research Group (1992): A novel gene containing a trinucleotide repeat that is expanded and unstable on Huntington's disease chromosome. Cell 72: $971-983$

Theilmann J, Kanani S, Shiang R, Robbins C, Quarrell O, Huuggins M, Hedrick A, Weber B, Collins C, Wasmuth JJ, Buetow KH, Murray JC, Hayden MR (1989): Non-random association between alleles detected at D4S95 and D4S98 and the Huntington's disease gene. J Med Genet 26: 676-681

Wasmuth JJ, Hewitt J, Smith B, Allard D, Haines JL, Skarecky D, Partlow E, Hayden MR (1988): A highly polymorphic locus very tightly linked to the Huntington's disease gene. Nature 332: 734-736

Whaley WL, Michiels F, MacDonald ME, Romano D, Zimmer M, Smith B, Leavin J, Bucan M, Haines JL, Gillium TC, Zehetner G, Smith C, Cantor CR, Frischauf A-M, Wasmuth JJ, Lehrach H, Gusella JF (1988): Mapping of D4S98/S114/S113 confines the Huntington's defect to a reduced physical region at the telomere of chromosome 4. Nucleic Acids Res 16: 11769-11780

Whaley WL, Bates GP, Novelletto A, Sedlacek Z, Cheng S, Romano D, Ormondroyd E, Allitto B, Lin C, Youngman S, Baxendale S, Bucan M, Altherr M, Wasmuth JJ, Wexler N, Frontali M, Frischauf AM, Lehrach H, MacDonald ME, Gusella JF (1991): Mapping of cosmid clones in Huntington's disease region of chromosome 4. Somat Cell Mol Genet 17: 83-91

Youngman S, Sarfarazi M, Bucan M, MacDonald M, Smith B, Zimmer M, Gilliam C, Frischauf A-M, Wasmuch JJ, Gusella JF, Lehrach H, Harper PS, Shaw DJ (1989): A new DNA marker (D4S90) is located terminally on the short arm of chromosome 4, close to the Huntington disease gene. Genonaics 5: 802-809 